\title{
The co-benefits for health of investing in active transportation
}

\author{
Billie Giles-Corti ${ }^{\mathrm{A}, \mathrm{D}}$, Sarah Foster ${ }^{\mathrm{A}}$, \\ Trevor Shilton ${ }^{\mathrm{B}}$ and Ryan Falconer ${ }^{\mathrm{C}}$ \\ ${ }^{\mathrm{A}}$ Centre for the Built Environment and Health, \\ School of Population Health, \\ The University of Western Australia \\ ${ }^{\mathrm{B}}$ Heart Foundation of Australia, Perth \\ ${ }^{\mathrm{C}}$ Formerly ${ }^{A}$, now Sinclair Knight Merz, Perth \\ ${ }^{\mathrm{D}}$ Corresponding author.Email: billie.giles-corti@uwa.edu.au
}

and it often forms part of a trip chain for public transport users. ${ }^{3}$ A number of reviews emphasise the importance of active transportation from health, economic, social, environmental and traffic management perspectives. ${ }^{4-11}$ They highlight environmental interventions that would facilitate a shift from motor vehicle-dependent suburbs to communities accessible by active modes, supported by high quality public transport (Box 1).

Box 1.

Trip chaining involves planning ahead and using one journey to achieve a number of objectives. For example, a public transport trip may be preceded or followed by a walking or cycling trip, either simply to get to or from the public transport stop, or to achieve another objective such as stopping at the newsagent to collect a newspaper to read on the bus.

Despite this evidence, there remains some distance between theory and practice. This paper seeks to contribute to the debate by discussing the health benefits and cobenefits of investing in policies and interventions to increase active transportation.

\section{Active transportation from a health perspective}

Building the habitual use of active transport into daily routines is one means to increase physical activity. ${ }^{2,5,10}$ Yet active transportation has rapidly declined in most developed countries over the past 3 decades. ${ }^{12-17}$

Globally, physical inactivity ranks second only to tobacco as a behavioural risk factor contributing to the burden of disease, ${ }^{18}$ and is a major risk factor for numerous chronic diseases and their determinants (e.g. cardiovascular disease, diabetes, colon and breast cancer and mental health). ${ }^{19}$ Physical inactivity globally causes about 1.9 million deaths each year, ${ }^{18}$ and in Australia alone over 13000 deaths each year. ${ }^{20}$ Worldwide $60 \%$ of adults ${ }^{21}$ and approximately half of Australian adults are insufficiently active to benefit their health. ${ }^{22}$ Furthermore, physical inactivity and sedentary behaviour are independent risk factors for obesity. ${ }^{19}$ Globally, an estimated 20 million children and 1.3 billion adults are either overweight or obese, ${ }^{23}$ as are two-thirds of men, one-half of women ${ }^{24}$ and one-fifth of children in Australia. $^{25}$
Active transportation includes travel by foot, bicycle and other non-motorised means (e.g. foot-powered scooters) ${ }^{2}$
Amid growing concerns about the effect of increasing levels of obesity and physical inactivity, climate change, population growth, increased traffic congestion declining oil supplies, many sectors are now prom improved health and traffic management through to environmental protection and the mitigation of climate change, promoting active transportation is increasingly recognised as a way to advance multiple agendas. 
The societal benefits of even a modest increase in those who are physically active could be large. For example, a fivepercentage point increase in the proportion of people doing 30 minutes each day of moderate activity could save around 600 Australian lives per year, with significant savings to the health system. ${ }^{26}$ A longitudinal study of Scandinavian adults found that, after adjustment, mortality rates in workers who cycled to work were $28 \%$ lower than others. ${ }^{27}$ Similarly, a Chinese study found a $20-50 \%$ lower risk of premature mortality in women who regularly exercised or cycled for transportation. ${ }^{28} \mathrm{~A}$ British study identified that children who walked or cycled to school were fitter than those who travelled by bus or car, with fitness $30 \%$ higher in boys who cycled and seven-fold higher in girls. ${ }^{29}$

Increasing physical activity levels is also an essential component of interventions required to combat obesity. ${ }^{21}$ A recent study of walking, cycling and obesity levels in Europe, North America and Australia found an inverse relationship between population active transportation and obesity levels, providing additional support for the benefits of promoting active transportation. ${ }^{30}$

Other health benefits would follow if vehicle miles travelled could be reduced. Motor vehicle transportation reduces air quality and contributes to the risk of respiratory diseases (e.g. asthma) and a range of chronic diseases, including cardiovascular disease. ${ }^{31,32}$ In Australia, 1\% of the burden of disease and injury is attributed to urban air pollution. $^{20}$

Urban air pollution varies by location, with particulate matter accumulating at traffic lights where flows are interrupted and vehicles idle. Pollution is, therefore, concentrated near major transport arteries, which are heavily trafficked and often congested. ${ }^{33}$ Studies emphasise that those living on or near busy roads (within 300 metres) are exposed to significantly higher levels of pollutants. ${ }^{34,35}$ Transport mode choice also influences pollutant exposure. Counter intuitively, vehicle drivers and their passengers may inhale up to 18 times more air pollution than those outside the vehicle, ${ }^{36,37}$ even compared with cyclists on busy streets. ${ }^{38}$

\section{Benefits of active transportation in sectors outside of health}

Beyond these significant health impacts, promoting active transportation confers numerous other social, environmental and economic benefits.

\section{Social benefits}

Pedestrian and cycling-friendly neighbourhood designs can facilitate incidental contacts between neighbours and appear to foster social capital (i.e. social networks, norms and trust). ${ }^{39,40}$ Numerous studies show positive associations between social capital and physical and mental health, and health promoting behaviours. ${ }^{41-43}$ Social capital may promote positive social norms while simultaneously controlling antisocial behaviours that can fuel feelings of insecurity. ${ }^{42}$

Increased pedestrian traffic also has the potential to influence neighbourhood safety by generating natural surveillance. Jane Jacobs asserted that urban environments with diverse land-uses would increase public safety and minimise fear by creating lively streets, monitored by local business proprietors and residents. ${ }^{44}$ Although greater pedestrian numbers can increase public nuisance crimes (e.g. littering, drug sales), pedestrian traffic appears protective against serious personal crime, which typically occurs when pedestrians (and, therefore, surveillance) are scarce. ${ }^{45}$

The provision of walkable neighbourhoods, with frequent accessible public transport is also an important strategy to limit 'transport poverty' (e.g. households without access to public transport). ${ }^{44}$ It also prevents marginalisation of other vulnerable subgroups with restricted mobility (e.g. children, older people and people with disabilities). ${ }^{46,47}$

\section{Reducing fossil fuel dependency}

Motorised travel is dependent on oil and is responsible for almost half the world's oil use. ${ }^{1}$ Over-reliance on fossil fuels is a concern because of its impact on greenhouse emissions ${ }^{48}$ and because it is a diminishing energy source. Globally, there is a need to diversify how populations are mobilised ${ }^{49}$ to mitigate declining oil supplies. While a shift to energy efficient vehicles is one part of the solution, a more comprehensive approach is required that also involves reducing vehicle miles travelled and increasing the transport choices available to people.

\section{Environmental benefits and climate change mitigation}

Motor vehicle travel can be detrimental to environmental health. ${ }^{1}$ In 2004, it was estimated that around $17 \%$ of carbon dioxide emissions associated with global energy use were from road transport. ${ }^{48}$ Transport emissions are rising faster than emissions from other sectors and are projected to be $80 \%$ higher than current levels by $2030 .{ }^{48}$ Moreover, personal motor vehicles are said to consume more energy and emit more greenhouse gas emissions per passenger-kilometre than other rail and road transport modes. ${ }^{48}$ Vehicle-generated greenhouse gas emissions are key contributors to global warming and climate change, making them important drivers for action.

Ewing and colleagues recently lamented the futility of global warming solutions that do not curb vehicle miles 
travelled. ${ }^{50}$ Citing the United States of America (USA) policy to prioritise increasing fuel efficient cars and reducing fuel's carbon content, they argued this policy overlooks vehicle miles travelled, the most important contributor to emissions. ${ }^{50}$ They estimated that if $60 \%$ of new US housing growth occurred in transit-oriented developments, about 85 million metric tonnes of $\mathrm{CO}_{2}$ could be saved annually by $2030 .^{50}$ Thus, while restraining personal vehicle ownership and use need to be policy priorities, ${ }^{48}$ this can only succeed if land use and transportation investments in pedestrian, cycling and transit infrastructure are prioritised.

Another compelling reason for curbing vehicle miles travelled is traffic congestion. Internationally, traffic congestion is a growing concern, given that over half the world's population already lives in cities; by 2030 , it is predicted that the urbanised population will reach five billion. ${ }^{51}$ Given the link between traffic congestion and air pollution, the rapid motorisation and urbanisation of developing countries are troubling. For example, between 2000 and 2020, Chinese emissions of carbon hydroxide, dioxide $\left(\mathrm{CO}_{2}\right)$ and monoxide, sulphur dioxide, volatile organic compounds, and nitrous oxide are predicted to rise up to 20 -fold. ${ }^{52}$

\section{Economic benefit}

From a health perspective there are economic benefits associated with investing in active transportation. In Australia, recent estimates indicate the direct and indirect costs to the Australian economy are $\$ 13.8$ billion for physical inactivity, ${ }^{53}$ and the direct costs $\$ 21$ billion for obesity and overweight. ${ }^{54}$ The annual costs of obesity and physical inactivity will continue to grow if current levels continue unabated. ${ }^{55-58}$

In New Zealand (NZ), Woodward modelled the impact on the health budget of a $5 \%$ increase in bicycle trips of less than $7 \mathrm{~km}$ (equivalent to levels in 1980). ${ }^{17}$ After accounting for additional costs associated with cycling injuries and fatalities, he estimated the annual net health savings amounted to $\$ 200$ million, or around 1.6\% of NZ's annual health budget. A comparable impact in Australia would save around \$1.7 billion on Australia's 2007-08 health expenditure. $^{59}$

Changes to neighbourhood design could also produce benefits for the local micro-economy. Increasing population densities and boosting local pedestrian and cycling traffic flows can increase the economic viability of cafes and corner stores, and improve access to jobs and services without increasing congestion or vehicle emissions. ${ }^{6}$

\section{The co-benefits of investing in active transportation} As depicted, investment in active transportation has the potential to produce substantial co-benefits across multiple sectors, ${ }^{60}$ including health. ${ }^{61,62}$ When benefits across multiple policy areas are considered concurrently, the term co-benefits is used. For example, the City of London's congestion tax not only reduced traffic by $30 \%$, and $\mathrm{CO}_{2}$, $\mathrm{NO}_{\mathrm{x}}$ (refers to $\mathrm{NO}$ and $\mathrm{NO}_{2}$ ) and large particulate emissions by $16-20 \%$, it also increased walking and cycling. ${ }^{63}$

Yet to date, relatively few studies have quantified the co-benefits of different approaches to changing modes of transport and the impacts on $\mathrm{CO}_{2}$ and health. ${ }^{64}$ Using Comparative Risk Assessment methods, Woodcock and colleagues estimated the effect of alternative transportation scenarios on health and carbon emissions, compared with business-as-usual. ${ }^{64}$ Table 1 summarises the results for London, indicating the co-benefits that could be derived from implementing strategies that increased both loweremission motor vehicle use and active transportation (i.e. a two-fold increase in distances walked and an eightfold increase in distances cycled from a very low base). Compared with a strategy focused solely on lower emission vehicle use, a combined intervention would almost double reductions in greenhouse emissions in London and would substantially reduce premature deaths and years of life lost to disability.

Nevertheless, to have an impact, active transportation requires land-use planning and infrastructure investment that creates pedestrian and cycling-friendly communities. ${ }^{62,65}$ Numerous studies now point to the importance of the built environment as a determinant of active transportation. ${ }^{2,3}$ Moreover, studies have recently begun to demonstrate the effectiveness of infrastructure investments in changing behaviour, ${ }^{62}$ and their cost effectiveness as a public health ${ }^{66,67}$ or transport and health ${ }^{68}$ intervention. Ignoring the implementation of complementary strategies (e.g. congestion pricing, increased transit use) or co-benefits, Ewing and colleagues ${ }^{65}$ recently estimated that a change in land-use planning in the USA (from urban sprawl to compact development) could reduce vehicle miles travelled by $20-40 \%$ and transportation greenhouse emissions by $7-10 \%$ by 2050 .

However few studies have comprehensively considered the co-benefits of land-use and transportation planning, including the co-benefits of strategies required to avoid negative impacts. For example, despite the benefits of compact urban development, strategies may be required to mitigate heat island effects (e.g. urban tree plantings, building living and lighter roofs) that could beneficially affect health. Moreover, in economic analyses, consideration of co-benefits is embryonic, ${ }^{68}$ yet this approach could substantially increase benefit-cost ratios associated with infrastructure investment. ${ }^{67}$ Together these are fruitful lines of future enquiry for multidisciplinary research teams that could provide evidence to help prioritise strategies. 
Table 1. Anticipated environmental and public health impacts of different land transportation strategies to reduce greenhouse gas emissions in London (adapted from Woodcock et al. 2009) ${ }^{64}$

\begin{tabular}{|c|c|c|c|c|}
\hline Estimates & $\begin{array}{l}\text { Business } \\
\text { as usual: } \\
2030 \\
\text { projection }\end{array}$ & $\begin{array}{l}\text { Lower carbon } \\
\text { emission } \\
\text { motor } \\
\text { vehicles alone }\end{array}$ & $\begin{array}{l}\text { Increased } \\
\text { active } \\
\text { transportation } \\
\text { alone }\end{array}$ & $\begin{array}{l}\text { Both lower carbon } \\
\text { emission motor } \\
\text { vehicles and increased } \\
\text { active transportation }\end{array}$ \\
\hline Change in transport $\mathrm{CO}_{2}$ from $1990(\%)$ & $4 \uparrow$ & $35 \downarrow$ & $38 \downarrow$ & $60 \downarrow$ \\
\hline Per person tonnes transport $\mathrm{CO}_{2}$ emissions & 1.17 & 0.73 & 0.69 & 0.45 \\
\hline $\begin{array}{l}\text { Air pollution (particulate matter with aerodynamic } \\
\text { diameter of } \leq 2.5 \mu \mathrm{m}) \text { concentrations }\left(\mu \mathrm{g} / \mathrm{m}^{3}\right)\end{array}$ & 8.2 & 7.8 & 7.7 & 7.4 \\
\hline \multicolumn{5}{|c|}{ Health effects (per million population) in 1 year compared with business as usual } \\
\hline Premature deaths & & 17 & 530 & 541 \\
\hline Years of life lost & & 160 & 5188 & 5295 \\
\hline Disability-adjusted life years & & 160 & 7332 & 7439 \\
\hline
\end{tabular}

\section{Conclusion}

As societies confront the economic, social and environmental effects of climate change, population growth traffic congestion and the burden of chronic disease, there is a unique opportunity to view the benefits of active transportation through a multi-sector lens. This paper shows that by taking a co-benefits approach to transport policy-reform, there is an opportunity to minimise carbon emissions and improve health. Studying the co-benefits of policy-options however is at the nascent stage. There are enormous opportunities to extend this approach to examine the cobenefits of active transportation encompassing broader perspectives e.g. reducing traffic congestion to achieve broader societal objectives related to socially and environmentally sustainable communities.

More multidisciplinary research is required that informs 'joined-up' policy solutions that cut across multiple policy agendas. The language of co-benefits is useful as it helps breaks down policy silos and presents additive (rather than discrete) benefits that could be incorporated in economic analyses to assess cost-effective strategies. Moreover, it could inform debate and facilitate assessment of policy alternatives to optimise outcomes for the community. Thus, articulating co-benefits should be at the forefront of future policy-reform discussions. An active transportation intervention not only tackles climate change, it could also deliver powerful co-benefits related to preventive health, social capital, traffic congestion and the economy.

\section{Acknowledgments}

BGC is supported by a NHMRC Senior Research Fellow Award (\#503712) and SF by a NHMRC Capacity Building Grant (\#458668). The editorial assistance provided by Lisa Bayly is gratefully acknowledged.

\section{References}

1. Woodcock J, Banister D, Edwards P, Prentice AM, Roberts I. Energy and transport. Lancet 2007; 370: 1078-88. doi:10.1016/ S0140-6736(07)61254-9

2. National Public Health Partnership. Promoting active transport: an intervention portfolio to increase physical activity as a means of transport. Melbourne: NPHP; 2001. Available from: http:// www.dhs.vic.gov.au/nphp/publications/sigpah/active.pdf (Accessed 3 May 2010.)

3. Villanueva K, Giles-Corti B, McCormack G. Achieving 10000 steps: a comparison of public transport users and drivers in a university setting. Prev Med 2008; 47(3): 338-41. doi:10.1016/ j.ypmed.2008.03.005

4. Transportation Research Board. Does the built environment influence physical activity? Examining the evidence, TRB Special Report 282. Washington, DC: TRB; 2005. Available from: http://onlinepubs.trb.org/onlinepubs/sr/sr282.pdf (Accessed 3 May 2010.)

5. National Institute for Health and Clinical Excellence. Promoting or creating built or natural environments that encourage and support physical activity. NICE; 2008. Available from: http://www.pedestrians-int.org/content/45/72008_ph.pdf (Accessed 3 May 2010.)

6. Heart and Stroke Foundation of Canada. Position statement: the built environment, physical activity, heart disease and stroke. Ottawa, Canada: HSF Canada; 2007.

Available from: http://www.heartandstroke.com/atf/cf/ \%7B99452D8B-E7F1-4BD6-A57D-B136CE6C95BF\%7D/ Built_Environment_PS-ENGLISH-07.pdf (Accessed 3 May 2010.)

7. Heart Foundation. Position statement: the built environment and walking. Melbourne: National Heart Foundation of Australia; 2009. Available from: http://www.heartfoundation.org.au/Site CollectionDocuments/Built_environment_position_statement_ FINAL_LR\%20for\%20web.pdf (Accessed 3 May 2010.)

8. Department of Transport and Department of Health UK. Active Travel Strategy. London: Department of Transport; 2010. Available from: www.dft.gov.uk/pgr/sustainable/ 
cycling/activetravelstrategy/pdf/activetravelstrategy.pdf (Accessed 3 May 2010.)

9. Kopelman P, Jebb SA, Butland B. Executive summary: Foresight 'Tackling Obesities: Future Choices' project. Obes Rev 2007; 8(Suppl 1): vi-ix. doi:10.1111/j.1467-789X.2007.00344.x

10. National Preventative Health Taskforce. Australia: the healthiest country by 2020. National Preventative Health Strategy - the roadmap for action. Canberra: Commonwealth of Australia; 2009. Available from: http://www.preventativehealth.org.au/ internet/preventativehealth/publishing.nsf/Content/nphs-roadmap/ \$File/nphs-roadmap.pdf (Accessed 3 May 2010.)

11. Billante V. Health promotion and sustainability through environmental design: A guide for planning. Christchurch: City of Christchurch; 2009. Available from: http://resources.ccc.govt. nz/files/HPSTED.pdf (Accessed 3 May 2010.)

12. Harten N, Olds T. Patterns of active transport in 11-12 year old Australian children. Aust N Z J Public Health 2004; 28: 167-72. doi:10.1111/j.1467-842X.2004.tb00931.x

13. Bradshaw R. School children's travel - the journey to school. Geography 2001; 86: 77-8.

14. French S, Story M, Jeffery R. Environmental influences on eating and physical activity. Annu Rev Public Health 2001; 22: 309-35. doi:10.1146/annurev.publhealth.22.1.309

15. Panter JR, Jones AP, van Sluijs EM. Environmental determinants of active travel in youth: A review and framework for future research. Int J Behav Nutr Phys Act 2008; 5: 34-48. doi:10.1186/1479-5868-5-34

16. van der Ploeg HP, Merom D, Corpuz G, Bauman A. Trends in Australian children traveling to school 1971-2003: Burning petrol or carbohydrates? Prev Med 2008; 46(1): 60-2. doi:10.1016/j.ypmed.2007.06.002

17. Woodward A, Lindsay G. Changing modes of travel in New Zealand cities. In: Howden-Chapman P, Stuart K, Chapman R, editors. Sizing up the city - Urban form and transport in New Zealand. Wellington: New Zealand Centre for Sustainable Cities centred at University of Otago; 2010.

18. World Health Organization. Global health risks: mortality and burden of disease attributable to selected major risks. Geneva, Switzerland: WHO; 2009. Available from: http://www.who.int/ healthinfo/global_burden_disease/GlobalHealthRisks_report_ full.pdf (Accessed 3 May 2010.)

19. World Health Organization. Obesity. Preventing and managing the global epidemic. WHO Technical Report Series 894. Geneva, Switzerland: WHO; 2000. Available from: http://whqlibdoc.who. int/trs/WHO_TRS_894.pdf (Accessed 3 May 2010.)

20. Begg S, Vos T, Barker B, Stevenson C, Stanley L, Lopez AD. The burden of disease and injury in Australia, 2003. Canberra: AIHW; 2007. Contract No.: PHE82. Available from: http:// www.aihw.gov.au/publications/hwe/bodaiia03/bodaiia03.pdf (Accessed 3 May 2010.)

21. World Health Organization. Global strategy on diet, physical activity and health. Geneva, Switzerland: WHO; 2004. May 2004; Report No.: WHA57.17. Available from: http://www. who.int/dietphysicalactivity/strategy/eb11344/strategy_ english_web.pdf (Accessed 3 May 2010.)

22. Armstrong T, Bauman A, Davies J. Physical activity patterns of Australian adults. Results of the 1999 National Physical Activity Survey. Canberra: AIHW; 2000. Available from: http://www.aihw.gov.au/publications/cvd/papaa/ papaa-c00.pdf (Accessed 3 May 2010.)

23. World Health Organization. Obesity and overweight. Geneva: WHO; 2006. Contract No.: Fact sheet 311. Available from: http://www.who.int/mediacentre/factsheets/fs311/en/print.html (Accessed 3 May 2010.)

24. AIHW. O'Brien K, Webbie K. Health, wellbeing and body weight: characteristics of overweight and obesity in Australia, 2001. Canberra: Australian Institute of Health and Welfare; 2004. Available from: http://www.aihw.gov.au/publications/ aus/bulletin13/bulletin13.pdf (Accessed 3 May 2010.)

25. Booth M, Wake M, Armstrong T, Chey T, Hesketh K, Mathur S. The epidemiology of overweight and obesity among Australian children and adolescents 1995-97. Aust NZJ Public Health 2001; 25(2): 162-9. doi:10.1111/j.1753-6405.2001.tb01840.x

26. Stephenson J, Bauman A. The cost of illness attributable to physical inactivity in Australia. Canberra: CDHAC and Australian Sports Commission; 2000. Available from: http://www.health. gov.au/internet/main/publishing.nsf/Content/health-pubhlthpublicat-document-phys_costofillness-cnt.htm/\$FILE/ phys_costofillness.pdf (Accessed 3 May 2010.)

27. Andersen LB, Schnohr P, Schroll M, Hein HO. All-cause mortality associated with physical activity during leisure time, work, sports, and cycling to work. Arch Intern Med 2000; 160: 1621-8. doi:10.1001/archinte.160.11.1621

28. Matthews CE, Jurj AL, Shu XO, Li HL, Yang G, Li Q et al. Influence of exercise, walking, cycling, and overall nonexercise physical activity on mortality in Chinese women. $\mathrm{Am} \mathrm{J}$ Epidemiol 2007; 165(12): 1343-50. doi:10.1093/aje/kwm088

29. Voss C, Sandercock G. Aerobic fitness and mode of travel to school in English schoolchildren. Med Sci Sports Exerc 2010; 42(2): 281-7. doi:10.1249/MSS.0b013e3181b11bdc

30. Bassett DRJ, Pucher J, Buehler R, Thompson DL, Crouter SE. Walking, cycling, and obesity rates in Europe, North America, and Australia. J Phys Act Health 2008; 5(6): 795-814.

31. Frank LD, Sallis JF, Conway TL, Chapman JE, Saelens BE, Bachman W. Many pathways from land use to health: Associations between neighborhood walkability and active transportation, body mass index, and air quality. $J$ Am Plann Assoc 2006; 72(1): 75-87. doi:10.1080/01944360608976725

32. Frumkin H, Frank L, Jackson R. Urban sprawl and public health: designing, planning and building for healthy communities. Washington DC: Island Press; 2004.

33. Riediker M, Williams R, Devlin R, Griggs T, Bromberg P. Exposure to particulate matter, volatile organic compounds, and other air pollutants inside patrol cars. Environ Sci Technol 2003; 37(10): 2084-93. doi:10.1021/es026264y

34. Roemer W, van Wijnen J. Daily mortality and air pollution along busy streets in Amsterdam, 1987-1998. Epidemiology 2001; 12(6): 649-53. doi:10.1097/00001648-200111000-00012

35. Zhu Y, Hinds W, Kim S, Siontas C. Concentration and size distribution of ultra-fine particles near a major highway. $J$ Air Waste Manage Assoc 2002; 52: 1032-42.

36. Elsom D. Smog alert: managing urban air quality. London: Earthscan Publications Ltd; 1996.

37. Dickens C. In-car particle exposure. London: Department of the Environment Transport and the Regions; May 2000. 
38. Rank J, Folke J, Jesperson P. Differences in cyclists and car drivers exposure to air pollution from traffic in the city of Copenhagen. Sci Total Environ 2001; 279: 131-6. doi:10.1016/ S0048-9697(01)00758-6

39. Leyden KM. Social capital and the built environment: the importance of walkable neighborhoods. Am J Public Health 2003; 93(9): 1546-51. doi:10.2105/AJPH.93.9.1546

40. Lund H. Pedestrian environments and sense of community. J Plann Educ Res 2002; 21(3): 301-12. doi:10.1177/ 0739456X0202100307

41. Wood L, Giles-Corti B. Is there a place for social capital in the psychology of health and place? J Environ Psychol 2008; 28(2): 154-63. doi:10.1016/j.jenvp.2007.11.003

42. McNeill LH, Kreuter MW, Subramanian SV. Social environment and physical activity: a review of concepts and evidence. Soc Sci Med 2006; 63(4): 1011-22. doi:10.1016/ j.socscimed.2006.03.012

43. Halpern D. Social Capital. Cambridge, UK: Polity Press; 2005.

44. Jacobs J. The Death and Life of Great American Cities. London: Jonathon Cape; 1961.

45. Loukaitou-Sideris A. Hot spots of bus stop crime: the importance of environmental attributes. $J$ Am Plann Assoc 1999; 65(4): 395-411. doi:10.1080/01944369908976070

46. Gleeson B, Randolph B. Social Disadvantage and Planning in the Sydney Context. Urban Policy Res 2002; 20(1): 101-7. doi:10.1080/08111140220131636

47. Currie G, Richardson T, Smyth P, Vella-Brodrick D, Hine J, Lucas $\mathrm{K}$ et al. Investigating links between transport disadvantage, social exclusion and well-being in Melbourne - Preliminary results. Transp Policy 2009; 16(3): 97-105. doi:10.1016/ j.tranpol.2009.02.002

48. Kahn R, Kobayashi SS, Beuthe M, Gasca J, Greene D, Lee DS et al. Transport and its infrastructure. In: Metz B, Davidson O, Bosch P, Dave R, Meyer L, editors. Climate change 2007: Mitigation contribution of working group III to the fourth assessment report of the intergovernmental panel on climate change. Cambridge and New York: Cambridge University Press; 2007.

49. Newman P, Kenworthy J. Sustainability and cities: overcoming automobile dependence. Washington DC: Island Press; 1999.

50. Ewing R, Bartholomew K, Winkelman S, Walters J, Chen D, McCann B et al. Growing Cooler: the evidence on urban development and climate change. Urban Land Institute; 2007.

51. United Nations Population Fund. State of world population 2007. Unleashing the potential of urban growth. UNFPA; 2008. Available from: http://www.unfpa.org/swp/2007/presskit/pdf/ sowp2007_eng.pdf (Accessed 3 May 2010.)

52. Han J, Hayashi Y. Assessment of private car stock and its environmental impacts in china from 2000 to 2020. Trans Res 2008; Part D(13): 471-8.

53. Medibank Private. The cost of physical inactivity. Canberra; October 2008. Available from: http://www.medibank.com.au/ Client/Documents/Pdfs/The_Cost_Of_Physical_Inactivity_ 08.pdf (Accessed 3 May 2010.)
54. Colagiuri S, Lee CM, Colagiuri R, Magliano D, Shaw JE, Zimmet PZ et al. The cost of overweight and obesity in Australia. Med J Aust 2010; 192(5): 260-4.

55. Access Economics. The growing cost of obesity in 2008: Three years on Melbourne: Diabetes Australia; 2008.

56. Access Economics. The shifting burden of cardiovascular disease in Australia. National Heart Foundation of Australia; 2005.

57. Allender S, Foster C, Scarborough P, Rayner M. The burden of physical activity-related ill health in the UK. $J$ Epidemiol Community Health 2007; 61(4): 344-8. doi:10.1136/ jech.2006.050807

58. Allender S, Rayner M. The burden of overweight and obesityrelated ill health in the UK. Obes Rev 2007; 8(5): 467-73. doi:10.1111/j.1467-789X.2007.00394.x

59. Australian Institute of Health and Welfare. Health expenditure Australia 2007-08. Health and Welfare Expenditure Series 37. Canberra: AIHW; 2008. Contract No.: Cat. No. HWE 46. Available from: http://www.aihw.gov.au/publications/hwe/ hwe-46-10954/hwe-46-10954.pdf (Accessed 3 May 2010.)

60. Mohan D, Tiwari D. Sustainable transport systems, linkages between environmental issues. Public transport, non-motorised transport and safety. Econ Politic Wly 1999; XXXIV(25): 1580-96.

61. Younger M, Morrow-Almeida HR, Vindigni SM, Dannenberg AL. The Built Environment, Climate Change, and Health Opportunities for Co-Benefits. Am J Prev Med 2008; 35(5): 517-26. doi:10.1016/j.amepre.2008.08.017

62. Rissel CE. Active travel: a climate change mitigation strategy with co-benefits for health. NSW Public Health Bull 2009; 20(1-2): 10-3. doi:10.1071/NB08043

63. Transport for London. Central London congestion charging. Fourth annual report. London: Transport for London; 2006.

64. Woodcock J, Edwards P, Tonne C, Armstrong BG, Ashiru O, Banister D et al. Public health benefits of strategies to reduce greenhouse-gas emissions: urban land transport. Lancet 2009; 374(9705): 1930-43. doi:10.1016/S0140-6736(09)61714-1

65. Ewing R, Bartholomew K, Winkelman S, Walters J, Anderson G. Urban development and climate change. J Urban 2009; 1(3): 201-16.

66. Wang G, Macera CA, Scudder-Soucie B, Schmid T, Pratt M, Buchner DA. Cost-Benefit Analysis of Physical Activity Using Bike/Pedestrian Trails. Health Promot Pract 2005; 6(2): 174-9. doi:10.1177/1524839903260687

67. Cavill N, Kahlmeier S, Rutter H, Racioppi F, Oja P. Economic analyses of transport infrastructure and policies including health effects related to cycling and walking: A systematic review. Transp Policy 2008; 15(5): 291-304. doi:10.1016/j.tranpol.2008. 11.001

68. Sælensminde K. Cost-benefit analyses of walking and cycling track networks taking into account insecurity, health effects and external costs of motorized traffic. Transportation Research Part A. Policy Pract 2004; 38(8): 593-606. doi:10.1016/j.tra.2004.04.003 